\title{
Numerical analysis of $\mathrm{CZ}$ growth process for sapphire crystal of $300 \mathrm{~mm}$ length: Part II. Predictions of crystal growth length without sub-grain defects
}

\author{
Ho Yong Shin*, Su Min Hong*,**, Jong Won Yoon***, Dae Yong Jeong** and Jong In Im, \\ *Simulation Center, Business Support Div., KICET, Seoul 153-801, Korea \\ **School of Material Sci. \& Eng., Inha Univ., Incheon 402-751, Korea \\ ***School of Material Sci. \& Eng., Dankook Univ., Cheonan 330-714, Korea
}

(Received October 17, 2013)

(Revised October 25, 2013)

(Accepted November 8, 2013)

\begin{abstract}
In this study, a c-axis displacement and an internal stress of the sapphire crystal of $300 \mathrm{~mm}$ length have been analyzed numerically and the crystal length having no sub-grain defects have been predicted. The hot zone structures were modified with the crucible geometry change and the additional insulation layer installed above the crucible. The simulation results show that the c-axis displacement difference between the original hot zone and others originated from the sub-grain defect formations in the sapphire ingot. When the crystal grown by $\mathrm{CZ}$ (Czochralski) grower using the modified hot zone, the crystal length having no sub-grain defects was increased about $57 \mathrm{~mm}$ maximum than the original one. When the simulation results compared with the experimental one, the predicted crystal length having no sub-grain defects were well corresponded with the experiment one in c-axis wafer of the $300 \mathrm{~mm}$ sapphire ingot. Therefore the sapphire crystal of $250 \mathrm{~mm}$ length having no sub-grain defects was successfully grown by $\mathrm{CZ}$ process.
\end{abstract}

Key words Sapphire, Czochralski, Hot zone structure, c-Axis displacement, Sub-grain defect

\section{$300 \mathrm{~mm}$ 길이의 사파이어 단결정 대한 $\mathrm{CZ}$ 성장공정의 수치해석: Part II. Sub- grain 결함이 없는 단결정 성장 길이의 예측}

신호용*, 홍수민 ***, 윤종원***, 정대용**, 임종인 *,

*한국세라믹기술원 기업지원본부 시뮬레이션센터, 서울, 153-801

**인하대학교 신소재공학과, 인천, 402-751

***단국대학교 신소재공학과, 천안, 330-714

(2013년 10월 17일 접수)

(2013년 10월 25일 심사완료)

(2013년 11월 8일 게재확정)

요 약 본 논문에서는 $\mathrm{CZ}$ 법으로 성장시킨 $300 \mathrm{~mm}$ 사파이어 단결정의 c-축 변형 특성 및 내부 응력 상태를 수치해석 하고, 사파이어 단결정에서 sub-grain 결함이 없는 성장 길이를 예측하였다. CZ 성장로의 hot zone 구조는 Ir 도가니 형상 및 상부 단열재 추가 설치 등으로 변경하였다. 본 연구의 시뮬레이션 결과, hot zone 구조 변경에 의한 c-축 변형 차이는 결정 내부에 sub-grain 결함 등이 내부에 생성되어 발생한다. Hot zone 구조 변경에 의해 sub-grain 결함이 없는 성장 길이 를 기존 보다 최대 약 $57 \mathrm{~mm}$ 정도 증가시킬 수 있을 것으로 예측되었다. 그리고 c-축 wafer에 대한 sub-grain 결함을 실험 적으로 분석하고, 시뮬레이션 예측 결과와 잘 일치하고 있는 것을 확인하였다. 그 결과, $\mathrm{CZ}$ 공정을 이용해 약 $250 \mathrm{~mm}$ 까지 sub-grain 결함이 없는 사파이어 결정을 성공적으로 성장시킬 수 있었다.

\footnotetext{
Corresponding author

Tel: +82-2-3282-2491

Fax: +82-2-3282-7801

E-mail: jongin@kicet.re.kr
} 


\section{1. 서 론}

$\alpha$-알루미나 $\left(\mathrm{Al}_{2} \mathrm{O}_{3}\right)$ 의 결정상인 corundum 구조는 symmetry group상 R-3C space 그룹의 사방정계(trigonal) symmetry에 해당하고, 약간 변형된 hexagonal 혹은 rhombohedral 구조로 나타낼 수 있다[1]. 사파이어 단결정 은 결정면의 방위에 따라 성장 속도 차이가 크고, 상대적 으로 성장이 용이한 a-축 결정은 Bridgman, Kyropoulos $(\mathrm{Ky})$, Heat Exchange Method(HEM) 등의 기술을 이용 하고, 상대적으로 난이한 c-축 결정은 Czochralski(CZ) 기술이 적용되고 있다[2, 3].

사파이어의 (0001) 면 보다 (1011) 면이 상대적으로 파괴에너지가 약해서 쉽게 분할될 가능성이 있고, 이론 적으로 9개의 분할 면 중 3개 면이 (1011)면과 평행하 다. 결정 성장과정에서 비균일한 온도분포는 slip에 의한 소성 변형을 일으켜 쌍정(twin) 및 전위(dislocation) 결 함 등을 생성한다. Slip 및 쌍정이 일어나는 방향은 성 장방향에 대한 결정의 방위 및 응력분포에 영향을 받는 것으로 알려져 있다[4-6]. 또한 사파이어의 일반적인 미 세결함인 전위는 종자 결정, 특정 응력을 초과한 열응력, 외부의 열적 기계적 변동 등으로 생성되고, 특정한 zone에 집중된 Mosaic 구조를 형성한다고 알려져 있다[7]. Subgrain boundary는 저각입계(low angle grain boundary: LGBA)라고도 하고, 결정 방위가 $10^{\circ}$ 미만으로 뒤틀린 두 Mosaic 구조의 경계를 말한다. Sub-grain boundary 는 충분한 활성화 에너지를 갖는 전위가 내부 열응력과 상호 작용하여 형성되고, 결정성장 과정 및 냉각 혹은 annealing 공정에서 발생한다고 알려져 있다 $[1,7,8]$.
$\mathrm{C}$-축 사파이어 경우, 결정성장의 전 공정 동안 결정 결함이 낮은 에너지를 갖는 (0001)면에서 생성되지 않도 록 성장 경계 면에서 대한 세심한 주의를 기울여야 하고, 성장로 hot zone 구조의 최적화 및 결정의 온도구배, 회 전속도, 인상속도 등의 공정변수 제어가 아주 중요하다.

본 논문에서는 $\mathrm{CZ}$ 성장로의 hot zone 구조 변경에 따 른 $300 \mathrm{~mm}$ 사파이어 단결정의 c-축 변형 특성 및 내부 응력 상태를 수치해석하고, 사파이어 결정에서 sub-grain 결함이 발생하기 시작하는 성장 길이를 예측하고자 하였 다. 그리고 $\mathrm{CZ}$ 법으로 성장시킨 c-축 wafer에 대한 subgrain 결함을 실험적으로 분석하고, 그 결과를 시뮬레이 션 예측 결과와 비교 분석하여 타당성을 검증하고자 하 였다.

\section{2. 사파이어 단결정의 결함 특성}

$\alpha$-알루미나 $\left(\mathrm{Al}_{2} \mathrm{O}_{3}\right)$ 의 결정상인 corundum 구조는 symmetry group상 R-3C space 그룹의 사방정계(trigonal) symmetry에 해당하고, 약간 변형된 hexagonal 혹은 rhombohedral 구조로 나타낼 수 있다. $\alpha$-알루미나의 결 정격자는 Fig. 1과 같이 $\mathrm{Al}^{3+}$ 와 $\mathrm{O}^{2-}$ 에 의해 이루어지고, 음이온인 $\mathrm{O}^{2-}$ 에 의해 hexagonal 충진 패턴을 형성한다. 양이온인 $\mathrm{Al}^{3+}$ 는 결정격자의 변형에 의해 대칭 중심에 위치하지 못하고, 6 개의 $\mathrm{O}^{2-}$ 에 의해 형성된 octahedron 공공의 위치한다. 산소이온에 위해 형성된 octahedron 공공의 상대적인 반경은 0.41 이고, $\mathrm{Al}^{3+}$ 이온의 반경은 0.57 이므로 격자가 약간 변형된다. $\mathrm{Al}^{3+}$ 및 $\mathrm{O}^{2-}$ 에 대한

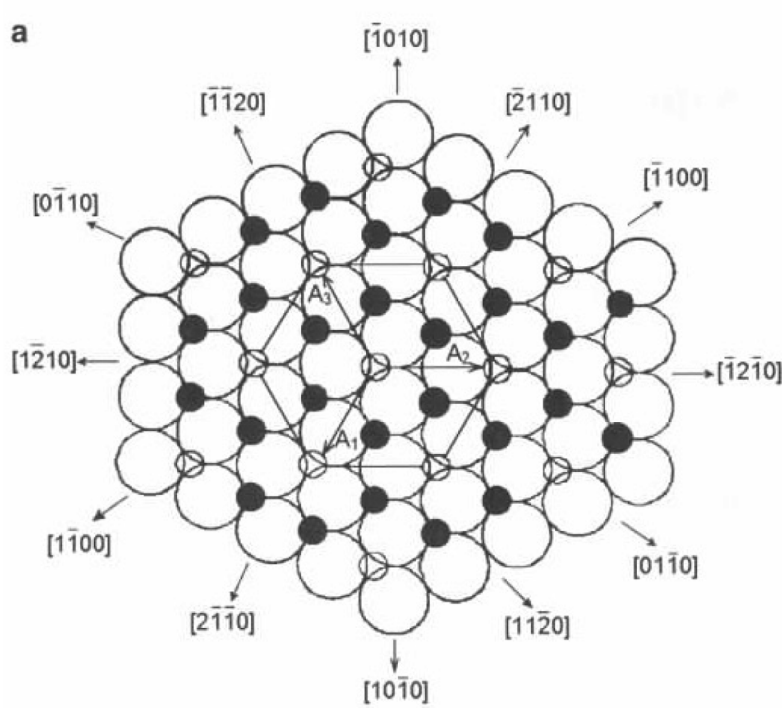

(a)

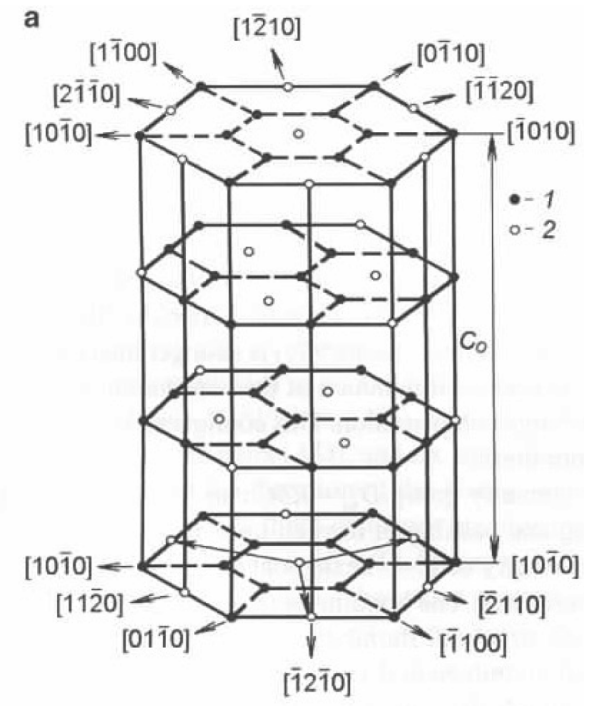

(b)

Fig. 1. (a) Schematic of the arrangement of $\mathrm{Al}^{3+}$ and octahedral hollows between two layers of $\mathrm{O}^{2-}$ in the basal plane and (b) hexagonal unit cell of the sapphire: (1) aluminum ions and (2) octahedral hollows [1]. 


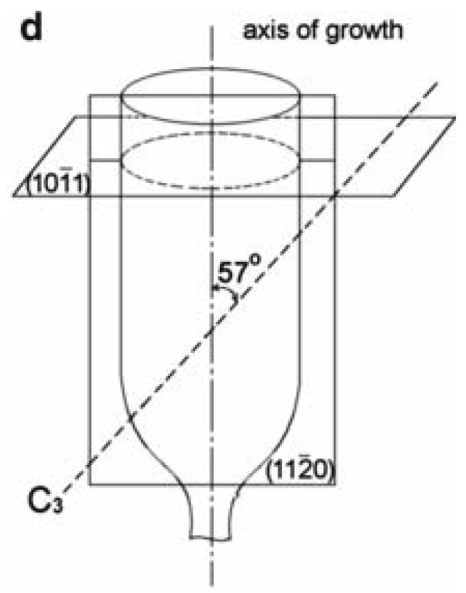

(a)

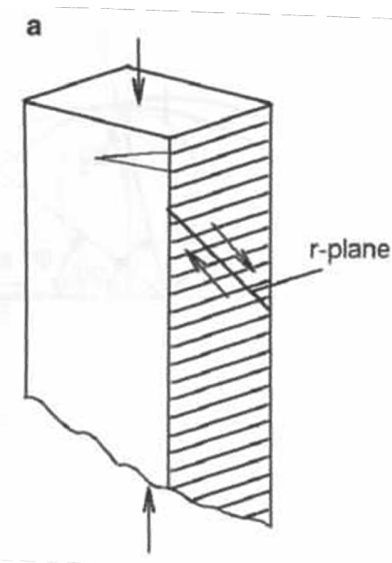

(b)

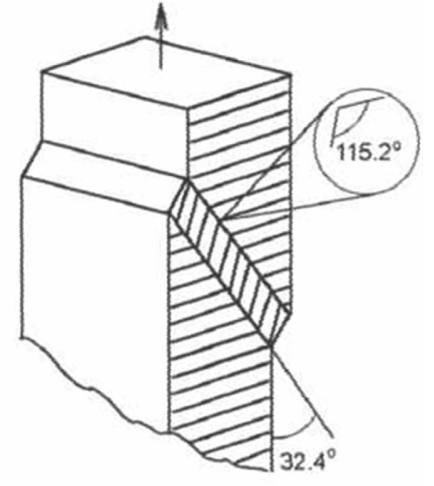

Fig. 2. (a) Location of the planes (1120) and (1011) with respect to the c-axis for chipping and (b) scheme of sapphire twining in the rhombohedronal plane upon compression $[1,4,5]$.

주위 원자 숫자는 각각 6 및 4 이고, 양이온은 $\mathrm{O}^{2-}$ 에 의 해 형성된 octahedron 공공의 $2 / 3$ 을 점유하고 있다고 알 려져 있다[1].

사파이어의 (0001) 면 경우, O-Al-Al-O-Al-O 층의 순 서로 결합이 이루어지고, (1011) 면의 경우, O-O-Al-OAl-O-O--O-Al-O-Al-O 층의 순서로 결합이 이루어져 있 다. (0001) 면은 분할될 조건에 해당하지 않지만, 원자간 거리가 $1.06 \mathrm{~A}$ 인 (1011) 면의 O-O의 결합은 아주 약해 서 상대적으로 쉽게 분할될 가능성이 있다고 한다[1].

이론적으로 사파이어 단결정은 9 개의 분할 면을 가지 고 있지만, 이 중 3 개 면이 (1011)면과 평행하고, c-축과 는 약 33 도 기울어져 있으며 이들 면에 수직인 방향은 c-축과 약 57도 정도 각도를 가지고 있다고 한다(Fig. 2(a) 참조). 그리고 (0001) 면 방향의 파괴 에너지는 약 $40 \mathrm{~J} / \mathrm{m}^{2}$ 정도이지만, (1011)면의 파괴 에너지는 훨씬 약 한 약 $6 \mathrm{~J} / \mathrm{m}^{2}$ 정도로 보고되고 있다[1].

결정 성장과정에서 비균일한 온도분포는 주로 slip에 의해 발생하는 소성변형을 야기한다. Slip이 일어나는 방향은 성장방향에 대한 결정의 방위 및 응력분포에 영 향을 받는 것으로 알려져 있다[1]. C-축으로 사파이어를 성장시킬 경우, slip은 $1470 \mathrm{~K}$ 이상의 온도에서 $(1 \overline{2} 10)$ 면과 (1011)면을 따라 주로 일어나는 것으로 알려져 있 다[1].

사파이어에서 twin은 냉각 혹은 $1,770 \mathrm{~K}$ 이하의 온도 의 소성 변형에 의해 일어나 발생한다고 알려져 있다. C-축 방향으로 압축응력을 받을 때 (1011)면을 따라 형 성되는 twin 형태를 Fig. 2(b)에 나타내었고, twin 경계 면의 두께는 약 $0.7 \mu \mathrm{m}$ 정도 된다고 한다. 또한 (1011) twin 면을 갖는 반사 대칭인 joint twin 및 $30 \sim 75 \mu \mathrm{m}$ 정도의 micro-twin이 형성되고, twin 층의 변형 정도 및 형상은 결정의 방위 및 가해지는 응력에 따라 달라진다

\section{[5-7].}

Dislocation은 사파이어 결정에서 일반적으로 발생하는 미세 결함 중 하나이고, 냉각 공정 중 발생하는 응력에 의하여 slip이 발생하고, 이에 의한 소성 변형으로 dislocation이 (0001) 및 (1120)에서 주로 발생한다. 만약 사파이어 결정의 방위에 따라 에너지 변동이 없을 경우, 전체 에너지를 최소화하기 위하여 dislocation이 결정 성 장면에 수직인 단거리 직선을 따라 결정의 한 층에서 다 른 층으로 전파하는 것이 바람직하다. 그러나 결정의 방 위에 따라 에너지가 다르기 때문에 dislocation은 성장면 과 특정한 각을 이루고 전파하게 된다. 사파이어 결정에 서 dislocation이 생성되는 원인으로는 크게 종자 결정의 seeding 과정, 특정 응력을 초과한 열응력에 의한 생성 및 증폭, 외부의 열적 기계적 변동 등을 요인으로 들 수 있고, Fig. 3의 Mosaic 구조와 같이 결정의 a면인 (11르) 면 방향으로 우선적으로 전파하여 특정한 zone에 집중 된 현상을 보인다고 한다 $[1,7,8]$.

Mosaic 구조는 결정 방위가 $10^{\circ}$ 미만으로 뒤틀린 미 세한 구조 영역이고, 두 영역의 경계를 저각입계(low

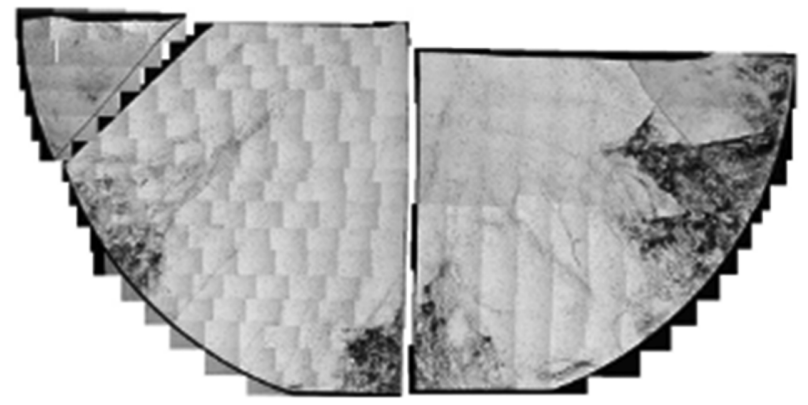

Fig. 3. A mosaic images of the etched c-axis grown wafer showing that dislocations are focused into regions along the a-axes [7]. 
angle grain boundary: LGBA) 혹은 sub-grain boundary 라고 한다[7, 8]. Dislocation LAGB는 결정의 냉각공정 혹은 annealing 공정에 주로 형성된다. 이 과정에서 dislocation은 이동에 필요한 충분한 활성화 에너지를 얻 고, 열응력과 상호 작용하여 이동하다 다른 slip 면 상의 dislocation과 평형을 이뤄 멈추게 되어 sub-grain boundary 를 형성한다. 또한 결정성장 과정에서 발생한 lineage 구 조도 sub-grain boundary를 형성한다[8]. 그러므로 사파 이어 결정에서 sub-grain boundary를 제거할 수 있는 기 본적인 방법은 dislocation 밀도 및 열응력을 감소시키는 것이다.

$\mathrm{C}$-축 사파이어 경우, 결정성장의 전 공정 동안 결정 결함이 낮은 에너지를 갖는 (0001)면에서 생성되지 않도 록 성장 경계 면에서 대한 세심한 주의를 기울여야 하고, 성장로 hot zone 구조의 최적화 및 결정의 온도구배, 회 전속도, 인상속도 등의 공정변수 제어가 아주 중요하다.

\section{3. 실험방법}

사파이어 단결정의 $\mathrm{CZ}$ 성장로는 원형으로 배치된 $\mathrm{RF}$ 코일 및 $\mathrm{Ir}$ 도가니를 포함한 온도 가열부, 융액 및 고-액 계면, 결정, 종자 결정 등을 포함하는 결정 성장부, 단열 재를 포함한 주위 구조물로 구성된다.

길이 $300 \mathrm{~mm}$ 사파이어 단결정의 성장공정을 수치해 석하기 위하여 $\mathrm{CZ}$ 성장로에 대한 $\mathrm{FEM}$ 모델을 구성하 고, 기존 연구에서 언급한 것과 동일한 구성 부품의 열 물성치를 사용하였다 $[9,10]$. 그리고 모든 구성 재료는 등방성 비자성체이고, $\mathrm{RF}$ 코일의 전류 및 전압 분포는 균일하며 전자기장은 도가니 및 히터의 온도와는 무관하 다고 가정하였다. 또한 사파이어 결정 내부의 온도특성 해석에 사파이어의 복사 및 굴절 특성을 반영하였다[1].

사파이어 단결정의 성장특성을 개선하기 위하여 Table 1 에 나타낸 바와 같이 Ir 도가니 형상 변경 및 상부 단

Table 1

Hot zone structures of the $\mathrm{CZ}$ grower for sapphire crystal of $300 \mathrm{~mm}$ length

\begin{tabular}{|c|c|c|}
\hline Case & $\begin{array}{l}\text { Additional insulation layers } \\
\text { (at upper part of the crucible) }\end{array}$ & Crucible (mm) \\
\hline A & No & $\begin{array}{l}\text { Diameter: Do } \\
\text { Height: Ho }\end{array}$ \\
\hline B & No & $\begin{array}{l}\text { Diameter: Do }-20 \\
\text { Height: } \mathrm{Ho}+40\end{array}$ \\
\hline $\mathrm{C}$ & Yes & $\begin{array}{l}\text { Diameter: Do } \\
\text { Height: Ho }\end{array}$ \\
\hline D & Yes & $\begin{array}{l}\text { Diameter: Do }-20 \\
\text { Height: } \mathrm{Ho}+40\end{array}$ \\
\hline
\end{tabular}

*Original cylindrical-type crucible dimension (mm): Do diameter and Ho height.
열재 보강 등을 통해 $\mathrm{CZ}$ 성장로의 hot zone 구조를 변 경하고, 결정 내부의 변형 및 응력특성을 예측하여 분석 하였다. 그리고 사파이어의 길이 방향인 c-축에 수직인 방향으로 절단하여 c-축 사파이어 wafer를 제작하고, 편 광현미경을 이용해 결정의 sub-grain 결함을 분석하였다.

\section{4. 결과 및 고찰}

C-축 사파이어는 낮은 에너지를 갖는 (0001)면에 수직 인 방향으로 성장하기 때문에 상대적으로 $\mathrm{a}$-축 결정보다 전위밀도가 높다고 알려져 있다. 결정에 형성된 전위는 내부의 열응력과 상호 작용하여 더 많은 전위를 생성하 게 되고, slip 및 twin, sub grain 등과 같은 결정 결함 으로 발전하게 된다. 또한 $\mathrm{CZ}$ 공정의 경우, 내부 온도 구배 및 결정 회전에 의해 melt의 유동이 발생하게 되고, 이에 의해 결정 내부에 기포 결함이 발생할 가능성이 더 크다. 특히 $300 \mathrm{~mm}$ 사파이어 $\mathrm{CZ}$ 성장로와 같이 원료의 투입량 및 내부 용적이 증가할 경우, 기포 및 전위, subgrain 등과 같은 결정 결함들이 더 잘 생성될 수 있다. 그러므로 무 결함의 결정을 성장시키기 위해서는 종자결 정의 투입에 의한 shoulder 형성단계인 $\mathrm{CZ}$ 성장공정의 초기단계부터 말기까지 세심한 주의를 기울어야 하고, 성장로 hot zone 구조의 최적화 및 결정의 온도구배, 회 전속도, 인상속도 등의 공정변수 제어가 아주 중요하다.

$300 \mathrm{~mm}$ 사파이어 결정의 기포 결함은 초기에는 shoulder 의 고액 계면 주위에 형성되고, 성장이 진행됨에 따라 body 및 tail의 중심부에 형성이 되는 것으로 관찰되었다. 결정의 길이가 $150 \mathrm{~mm}$ 에서 $300 \mathrm{~mm}$ 로 길어짐에 따라 성장로 내부 구조 체적 역시 약 $30 \%$ 정도 증가하도록 변경하여야 한다. 이러한 성장로 구조 변경으로 내부 열 분포 및 융액 유동패턴이 변화되고, 융액 중심부에서 온 도 저하 및 와류 생성으로 인해 다량의 기포가 결정으로 유입된 것이라고 판단된다. 이를 방지하기 위하여 성장 로의 RF코일부 위치 변경하여 하부 발열을 강화하였고, 융액의 자연대류를 향상시킬 수 있도록 결정의 회전속도 등 공정변수를 제어하여 결정의 기포 결함을 제거하였다.

$\mathrm{CZ}$ 성장로 hotzone의 최적설계를 위해 도가니 형상 및 상부 단열재 구조 등을 변경하여 시뮬레이션을 해석 하였다. Table 1과 같이 hot zone 구조의 해석을 수행하 였으며, 성장된 결정의 변형 및 응력 특성을 분석하였다. 사파이어 결정의 길이 변화에 따른 c-축 변형특성 및 내 부 응력특성의 변화를 분석한 결과를 각각 Fig. 4 및 Fig. 5에 나타내었다. Fig. 4의 (a)와 (b)는 각각 사파이 어 결정의 중심 및 외부 표면 근처에서 $\mathrm{c}$-축 변형특성을 해석하여 분석한 결과이다.

예측 결과처럼 $300 \mathrm{~mm}$ 사파이어 결정의 c-축 방향 변 


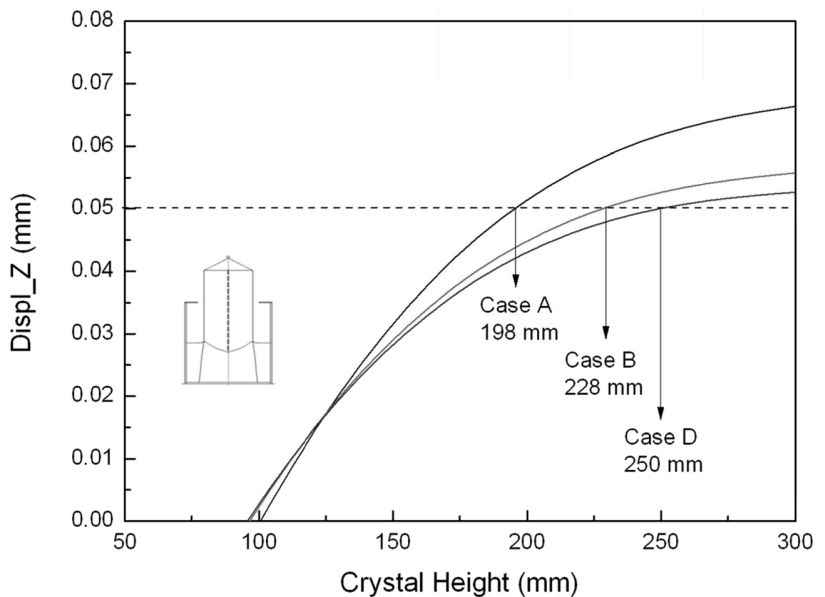

(a)

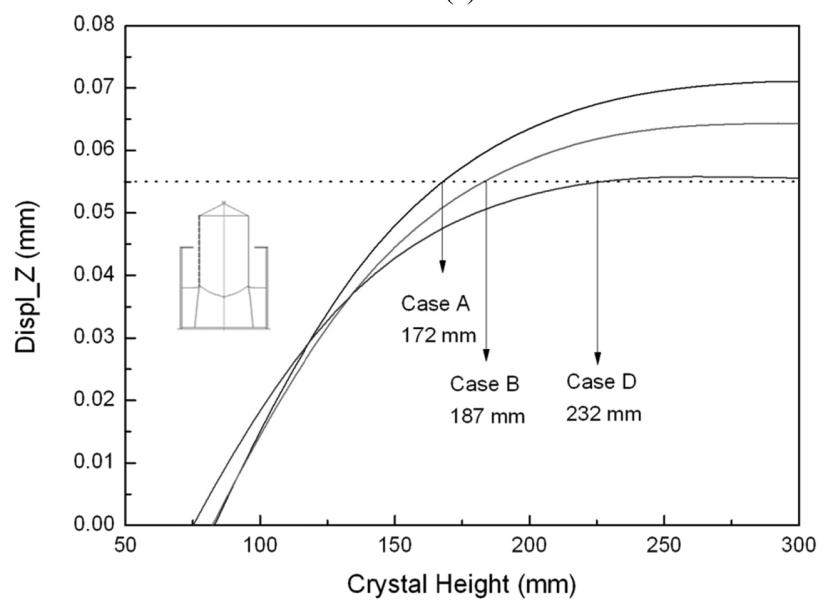

(b)

Fig. 4. Simulated $\mathrm{z}$ displacements of the sapphire crystal with the grown length: (a) at center position and (b) at surface position.

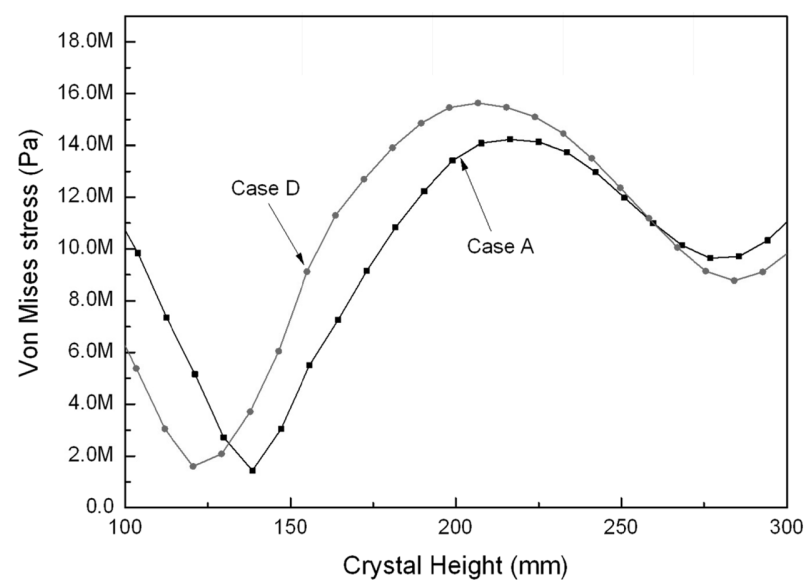

Fig. 5. Simulated Von Mises stress of the sapphire crystal with the grown length.

형은, 길이가 약 $100 \mathrm{~mm}$ 이상인 경우, 성장 길이가 증 가함에 따라 증가하다가 일정한 값으로 수렴하는 경향을 보이고 있다(Fig. 4(a) 참조). 그리고 c-축 방향 변형 정 도는 기존 구조인 A 경우에 가장 크고, hot zone 구조
를 변경시킨 $\mathrm{B}$ 경우 및 $\mathrm{D}$ 경우로 갈수록 감소하는 것 으로 나타났다. Table 1에서 알 수 있듯이, hot zone 구 조 $\mathrm{B}$ 는 기존 성장로에서 $\mathrm{Ir}$ 도가니의 직경을 감소시키고, 높이를 증가하여 발열 특성을 보강한 경우이고, $\mathrm{D}$ 의 경 우는 추가로 상부 단열재를 설치하여 열의 방출을 차단 한 경우이다.

일반적으로 재료의 변형은 결정에 가해진 외부 힘, 자 체 무게에 의한 하중, 내부 온도분포, 내부 결함 생성, 열응력 등에 의하여 영향을 받으며 이러한 인자들이 고 려되어 해석을 수행하였다. $\mathrm{CZ}$ 성장공정에 대한 결정의 회전속도 및 인상속도가 동일하고, 외부에서 어떤 힘도 가하지 않으므로 외부 힘에 의한 결정의 변형은 발생하 지 않는다. 또한 사파이어 결정의 직경 및 길이가 동일 하므로 사파이어 결정의 자중에 의한 c-축 변형 정도는 동일할 것으로 판단된다. 그리고 기존의 hot zone A 구 조를 도가니 형상 변경 및 상부 단열재 보강에 의해 $\mathrm{D}$ 구조로 변경함에 따라 단결정 내부 온도가 약 $10 \mathrm{~K}$ 정 도 향상 되는 것으로 분석되었다[11]. 일반적으로 온도 가 상승하게 되면, 재료의 변형이 쉽게 되므로 기존 $\mathrm{A}$ 경우보다 $\mathrm{D}$ 의 경우가 사파이어 하중에 의하여 더 많이 변형된다고 예측할 수 있다. 그러나 hot zone A가 D의 경우 보다 결정 내부의 온도가 낮음에도 불구하고, c-축 방향의 총 변형량이 더 큰 것으로 보아 내부 온도분포의 영향이 아닌 결정의 내부결함의 생성 정도에 의해 주로 영향을 받는 것으로 판단된다.

사파이어 결정의 c-축 방향 변형은 초기에 자체 하중 에 의해 변형이 되다가 성장이 더 진행됨에 따라 전위, slip, 쌍정 등에 의해 형성된 sub grain 결함에 의해 추 가적인 변형이 이루어 진다고 가정하고, sub-grain 결함 이 생성되는 시점을 예측하였다. 결정의 중심부가 표면 보다 상대적으로 자유롭게 변형되지 않기 때문에 결정의 중심 및 표면에서 sub-grain 결함이 생성되는 시점을 각 각 $50 \mathrm{~mm}$ 및 $55 \mathrm{~mm}$ 정도 c-축 방향 변형이 이루어 진 시점이라 가정하여 분석하였다.

기존 hot zone을 사용한 경우, 사파이어 결정의 subgrain 결함은 표면 및 중심부에서 약 $172 \mathrm{~mm}$ 및 198 $\mathrm{mm}$ 정도의 길이로 성장될 때 생성되기 시작할 것으로 예측되고, 평균적으로 약 $184 \mathrm{~mm}$ 정도의 길이로 성장될 때 생성되기 시작할 것으로 판단된다. $\mathrm{CZ}$ 성장로의 hot zone을 $\mathrm{B}$ 및 $\mathrm{C}, \mathrm{D}$ 와 같이 변경하여 사용할 경우, 사파 이어 결정의 sub-grain 결함은 각각 약 $201 \mathrm{~mm}$ 및 215 $\mathrm{mm}, 241 \mathrm{~mm}$ 정도의 길이로 성장될 때 생성되기 시작 할 것으로 분석되었다. 이상의 결과로부터 도가니의 형 상 변경 및 상부 단열재 추가 설치에 의해 기존 보다 sub-grain 결함의 생성 시점이 각각 약 $17 \mathrm{~mm}$ 및 31 $\mathrm{mm}$ 정도 지연되고, 두 경우를 모두 이용해 hot zone을 보강시킬 경우 기존보다 sub-grain 결함의 생성 시점이 
약 $57 \mathrm{~mm}$ 정도 지연될 수 있다고 판단된다.

$\mathrm{CZ}$ 법으로 성장시킨 $300 \mathrm{~mm}$ 사파이어 결정의 내부응 력 상태를 해석하여 비교 분석한 Fig. 5의 결과에서 알 수 있듯이, $\mathrm{CZ}$ 성장로의 hot zone을 변경한 D 경우가 기존의 A 경우보다 상대적으로 높은 응력 상태를 보이 고 있다. 일반적으로 사파이어 결정에 sub-grain 등 내부 결함이 생성 될 경우, 결정 내부의 일부 응력이 제거되 어 상대적으로 결정 내부 응력은 감소하게 될 것이다. 그러나 hot zone A 경우 보다 D 경우를 이용하여 성장 시킨 사파이어의 경우, 결정의 내부에 결함이 생성되지 않아 약 $125 \mathrm{~mm}$ 부터 $250 \mathrm{~mm}$ 길이 구간에 상대적으로 높은 내부 응력을 보유하고 있는 것으로 판단된다. 이 결과는 결정의 c-축 변형을 이용해 sub-grain 발생 시점 에 대한 예측 결과와 일치하는 결과이다(Fig. 4 참조).

시뮬레이션 결과를 검증하고자 $\mathrm{CZ}$ 법으로 성장시킨 사 파이어 결정의 sub-grain 결함을 분석하고, 그 결과를 Fig. 6 및 Fig. 7에 나타내었다. 두 장의 편광필름 사이 에 wafer를 거치시키고 광원을 조사하여 결함을 확인하

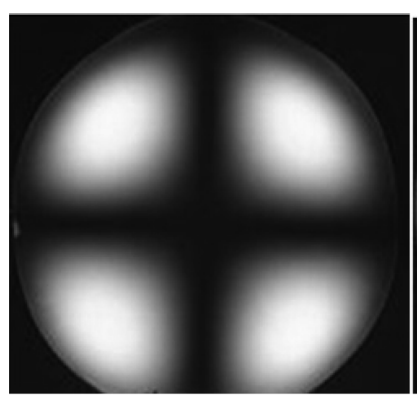

(a)

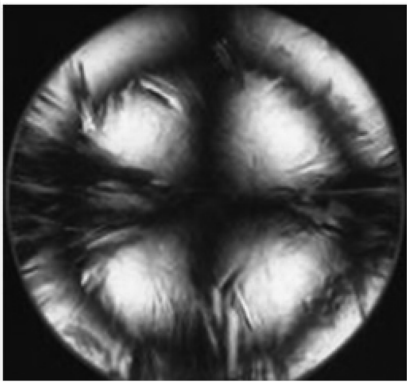

(b)
Fig. 6. Polarization microscope images of the c-axis sapphire wafer (a) exhibiting no the sub-grains and (b) showing the lineage of the sub-grains.

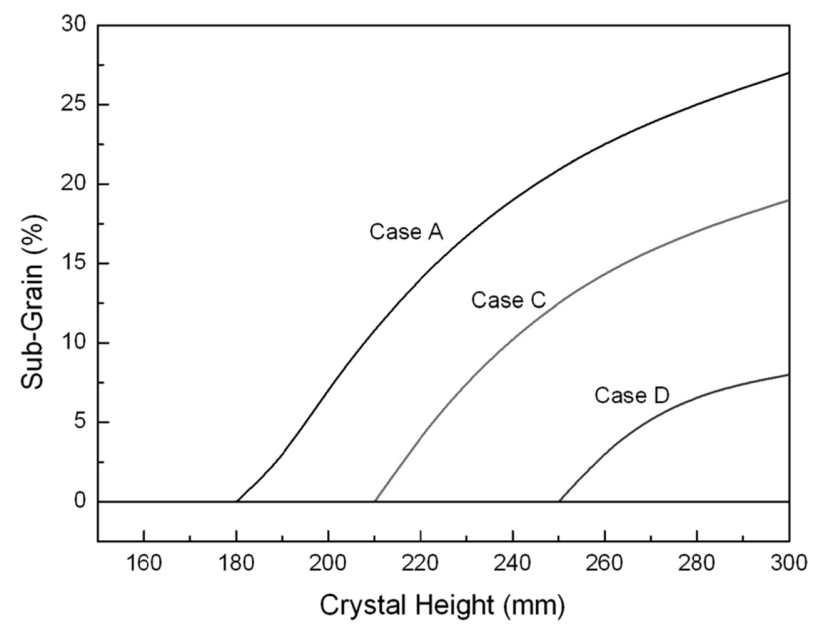

Fig. 7. Experimental results for the percentage of the sub-grain defects in the c-axis sapphire wafer with the crystal length grown using the $\mathrm{CZ}$ method.
Table 2

Analysis results for the crystal length having no the sub-grain defects in the sapphire ingot (unit: $\mathrm{mm}$ )

\begin{tabular}{|c|c|c|c|c|}
\hline \multirow{2}{*}{ Case } & \multicolumn{3}{|c|}{ Simulation results } & \multirow{2}{*}{$\begin{array}{l}\text { Experiment } \\
\text { results }\end{array}$} \\
\hline & Center & Surface & Avg. & \\
\hline A & 195 & 172 & 184 & 180 \\
\hline B & 215 & 187 & 201 & - \\
\hline $\mathrm{C}$ & 230 & 200 & 215 & 210 \\
\hline $\mathrm{D}$ & 250 & 232 & 241 & 250 \\
\hline
\end{tabular}

는 Cross-nicole 검사법을 이용하여 결정의 Sub-grain을 분석하였다. Fig. 6은 sub-grain 결함이 존재하지 않는 경우와 존재하는 c-축 사파이어 wafer의 편광현미경 사 진을 나타낸 것이다. 그리고 Fig. 7은 사파이어 결정의 성장 길이에 따라 sub-grain 결함의 함량을 분석한 결과 이다.

Fig. 7의 결과에서 알 수 있듯이, 기존 hot zone을 사 용한 경우, sub-grain 결함은 성장의 길이가 증가함에 따 라 약 $180 \mathrm{~mm}$ 길이에서 발생하여 약 $27 \%$ 정도까지 지속적으로 증가하는 것으로 나타났다. 그리고 hot zone $\mathrm{C}$ 를 사용한 경우, sub-grain 결함은 약 $210 \mathrm{~mm}$ 길이에 서 발생하여 약 $18 \%$ 정도까지 증가하고, hot zone $\mathrm{D}$ 를 사용한 경우, 약 $250 \mathrm{~mm}$ 길이에서 발생하여 약 $7 \%$ 정 도까지 증가 지속적으로 증가하는 것으로 분석되었다.

$\mathrm{CZ}$ 성장로의 hot zone 변경에 의해 성장시킨 사파이 어 결정의 sub-grain 결함의 발생 길이에 대한 수치해석 결과와 실험적 결과를 요약하여 Table 2에 나타내었다. 사파이어 결정의 sub-grain 결함의 발생 길이에 대한 수 치해석 결과는, hot zone $\mathrm{A}$ 와 $\mathrm{C}$ 의 경우, 실험에 비해 약 $5 \mathrm{~mm}$ 정도 높게 분석되었고, hot zone $\mathrm{D}$ 의 경우, 수치해석 결과가 실험치에 비해 약 $9 \mathrm{~mm}$ 정도 낮은 것 으로 분석되었다.

이상의 결과로부터 사파이어 단결정의 sub-grain 결함 의 발생 시점을 예측하는 방법에 대한 시뮬레이션 분석 기법의 타당성 및 유용성을 확인하였다. 향후 사파이어 의 c-축 변형에 자체 하중 및 내부 결함이 미치는 영향 을 분석하여 sub-grain 생성에 대한 c-축 변형 기준 설 정이 필요하고, 결정의 다양한 응력성분 중 결정 결함에 생성에 주로 기여하는 성분이 무엇인가에 대한 추가적인 연구가 필요하다.

\section{4. 결 론}

본 논문에서는 $\mathrm{CZ}$ 법으로 성장시킨 $300 \mathrm{~mm}$ 사파이어 단결정의 c-축 변형 특성 및 내부 응력 상태를 수치해석 하고, 사파이어 결정에서 sub-grain 결함이 없는 성장 길 이를 예측하였다. CZ 성장로의 hot zone 구조는 Ir 도가 
니의 직경 및 높이, 상부에 단열재를 추가 설치하여 변 경한 경우로 한정하였다. 본 연구의 시뮬레이션 결과, 사 파이어 결정의 c-축 변형은 자체 하중 및 내부 온도, 내 부 결함 생성 등에 의하여 온도가 증가함에 따라 증가하 다가 일정한 값에 수렴하는 특성을 나타낸다. 또한 hot zone 구조의 변경으로 c-축 변형 및 내부 응력 특성의 차이는 결정 내부에 생성된 sub-grain 등 결함이 주요한 원인인 것으로 판단된다. 그리고 도가니 형상 변경 및 상부 단열재 설치 등으로 hot zone 구조를 변경한 경우, sub-grain 결함이 없는 성장 길이를 각각 기존 보다 최 대 약 $57 \mathrm{~mm}$ 정도 증가시킬 수 있을 것으로 예측되었 다. 그리고 $\mathrm{CZ}$ 법으로 성장시킨 c-축 wafer에 대한 subgrain 결함을 실험적으로 분석하고, 시뮬레이션 예측 결 과와 잘 일치하고 있는 것을 확인하였다. 최종적으로 $\mathrm{CZ}$ 성장법을 이용해 약 $250 \mathrm{~mm}$ 길이까지 sub-grain 결 함이 존재하지 않는 $300 \mathrm{~mm} \mathrm{c}$-축 사파이어 단결정을 성공적으로 성장시킬 수 있었다.

본 연구를 통해서 사파이어 단결정의 sub-grain 결함 의 발생 시점을 예측하는 방법에 대한 시뮬레이션 분석 기법의 타당성 및 유용성을 확인하였다. 향후 사파이어 의 c-축 변형에 대한 내부 결함의 영향 및 sub-grain 생 성 기준, 결함 생성에 영향을 주는 응력성분 등에 대한 상세한 분석이 필요하다.

\section{참 고 문 헌}

[ 1 ] E.R. Dobrovinskaya, L.A. Lytvynov and V. Pishchik,
"Sapphire material, manufacturing, applications" (Spinger Press, 233 Spring Street, New York, NY 10013, USA, 2009), p.55, ISBN: 978-0-387-85694-0.

[2] R. Feigelson, "50 years of progress in crystal growth", J. Crystal Growth 264 (2004) xi.

[ 3 ] H. Scheel, "Historical aspects of crystal growth technology", J. Crystal Growth 211 (2000) 1.

[4] D.C. Harris, Proceedings of SPIE Conference on Window and Dome Technologies and Materials VI 3705 (1999) 2.

[ 5 ] D.C. Harris, F. Shmid, D. Black, et al., Proceedings of SPIE Conference on Window and Dome Technologies and Materials VII 3050 (2001) 226.

[6] T.M. Regan, D.C. Harris, R.M. Stroud, et al., Proceedings of SPIE Conference on Window and Dome Technologies and Materials VII 4375 (2001) 31.

[ 7 ] F.J. Bruni, C.M. Liu and J.S. Sundberg, "Will Czochralski growth of sapphire once again prevail?", ACTA Physica Polonica A. 124(2) (2013) 213.

[ 8 ] H. Li, G. Zhao, X. Zeng, Z. Qian, J. Guo, S. Zhou and J. Xu, "Low-angle Boundary in High-temperature Scintillating Crystal Ce:YAP”, J. Inorganic Materials 19(5) (2004) 1186

[9] S. Lim, H. Shin, J. Kim and J. Im, "Finite element analysis for czochralski growth process of sapphire single crystal”, J. Korean Cryst. Growth Cryst. Technol. 21(5) (2011) 193.

[10] H. Shin, J.H. Im and J. Im, "Numerical analysis of sapphire crystal growth process using Ky and CZ method", J. Korean Cryst. Growth Cryst. Technol. 23(2) (2013) 59.

[11] H. Shin, J. Kim, J. Yoon, D. Jeong and J. Im, "Numerical analysis of $\mathrm{CZ}$ growth process for sapphire crystal of $300 \mathrm{~mm}$ length: Part I. Influence of hot zone structure modification on crystal temperature", J. Korean Cryst. Growth Cryst. Technol. (2013) (To be published). 